\title{
Penerapan Model Problem Based Learning Untuk Meningkatkan Kemampuan Memecahkan Masalah Dan Sikap Peduli Lingkungan Siswa SMP Darul Aminin NW Aikmual Tahun 2019
}

\author{
Asrorul Azizi ${ }^{1,}$ Mulia Rasyidi $^{2}$ \\ ${ }^{1}$ Program studi Pendidikan guru Pendidikan Anak Usia Dini \\ ${ }^{2}$ Program Studi Pendidikan Ilmu Pengetahuan Alam \\ asroruljilid3@gmail.com ${ }^{1}$ mulia.rasyidi@gmail.com²
}

\begin{abstract}
Abstrak. Era globalisasi menuntut sumber daya manusia yang memiliki kemampuan memecahkan masalah. Kemampuan ini dikembangkan melalui pendidikan IPA. Hasil observasi menemukan peserta didik kurang memperoleh kemampuan memecahkan masalah dan pembentukan sikap peduli lingkungan. Salah satu model pembelajaran yang berawal dari masalah adalah Problem Based Learning. Dalam Problem Based Learning peserta didik menyelesaikan masalah nyata tentang lingkungan dan berhubungan dengan kepentingan masyarakat. Peserta didik yang menjadi pemecah masalah diharapkan memiliki sikap peduli lingkungan. Penelitian ini bermaksud mengkaji pengaruh penggunaan Problem Based Learning dalam meningkatkan kemampuan memecahkan masalah dan sikap peduli lingkungan. Subjek yang diteliti merupakan peserta didik kelas VII SMP Darul Aminin NW Aikmual. Metode penelitian kuasi eksperimen dengan rancangan kelompok kontrol (pra tes dan pos tes). Kelompok eksperimen mendapatkan $P B L$ sedangkan kelompok kontrol mendapatkan bukan $P B L$. Kemampuan memecahkan masalah diukur dengan soal uraian. Sikap peduli lingkungan dihimpun dengan angket sikap eksplisit dan sikap implisit. Teknik analisis data menggunakan SPSS for window versi 21. Kemampuan memecahkan masalah menggunakan Independen Test, sedangkan sikap peduli lingkungan menggunakan Mann-Whitney. Hasil penelitian menunjukkan peningkatan kemampuan memecahkan masalah peserta didik yang memperoleh $P B L$ ( $\bar{x}=0,440)$ lebih tinggi dari peserta didik yang memperoleh pembelajaran bukan $P B L(\bar{x}=0,281), \mathrm{t}$ $(56)=2,213>t_{\text {tabel } \square}=1,671$. Sikap peduli lingkungan peserta didik yang memperoleh PBL lebih tinggi dari peserta didik yang memperoleh pembelajaran bukan PBL. Dengan demikian Model Problem Based Learning berpengaruh signifikan terhadap peningkatan kemampuan memecahkan masalah dan sikap peduli lingkungan peserta didik SMP Darul Aminin NW Aikmual.
\end{abstract}

Kata Kunci: Problem Based Learning, Kemampuan Memecahkan Masalah, Sikap Peduli Lingkungan, Dan Cara Mencegah Kerusakan Alam.

\section{A. PENDAHULUAN}

Perkembangan IPTEK saat ini mengakibatkan beragam perubahan yang begitu cepat pada kehidupan di semua tingkat lapisan masyarakat. Ragam perubahan ini memberi tuntutan yang berbeda sehingga menjadi tekanan pada perilaku manusia untuk dapat memenuhi kebutuhan dan tuntutan hidupnya. Pemenuhan kebutuhan masyarakat terhadap tuntutan hidup berdampak pada semakin meningkatnya persaingan serta permasalahan-permasalahan kehidupan yang semakin ketat dan komplek. Kenyataan ini menuntut adanya sumber daya manusia (SDM) yang memiliki kemampuan dalam memecahkan permasalahan. Untuk itu, kemampuan dalam memecahkan masalah perlu diperkenalkan dan dikembangkan secepat mungkin dan sedini mungkin kepada setiap masyarakat khususnya peserta didik yang masih di bangku sekolah. Pendidikan formal merupakan salah satu sarana yang paling strategis dalam mengembangkan kemampuan memecahkan masalah sedini mungkin kepada peserta didik.

Berdasarkan definisi pendidikan (dalam UU RI No. 20 tahun 2003 tentang Sisdiknas) tergambar bahwa pendidikan adalah rangkaian kegiatan yang sistematis dan terencana untuk mengembangkan potensi peserta didik menjadi suatu kemampuan atau kompetensi. Pengajaran, pelatihan, dan bimbingan secara 
bersama-sama membantu proses pendidikan dalam usaha membangun seluruh kepribadian anak yang meliputi aspek intelektual/kognitif, sikap/afektif, dan keterampilan /psikomotor.

Kemampuan memecahkan masalah dapat ditanamkan kepada peserta didik melalui kegiatan pembelajaran IPA (sains). IPA (sains) bukan hanya kumpulan pengetahuan benda atau makhluk hidup sebagaimana yang tertuang dalam buku teks, tetapi memerlukan kerja, cara berpikir, dan cara memecahkan masalah (Winaputra dalam Samatowa, 2010, hlm. 3). Salah satu tujuan mata pembelajaran IPA di SMP adalah agar peserta didik memiliki kemampuan mengembangkan keterampilan proses untuk menyelidiki alam semesta, memecahkan masalah, membuat keputusan dan menanamkan serta menumbuhkan nilai-nilai karakter. Peserta didik lulusan SMP harus menunjukkan kemampuan memecahkan masalah sederhana dalam kehidupan seharihari.

Menurut Depdiknas (dalam Taufik, T. dkk. 2010) kondisi obyektif pembelajaran di sekolah saat ini menunjukkan permasalahan antara lain: siswa hanya mampu menyajikan tingkat hapalan yang baik, siswa tidak mampu menghubungkan materi dengan bagaimana pengetahuan tersebut akan dipergunakan/ dimanfaatkan, siswa memiliki kesulitan untuk memahami konsep akademik. Kelemahankelemahan pembelajaran IPA di atas, dirasakan juga di sekolah tempat penelitian.

Jeremy (dalam Taufik T, dkk. 2010) mengemukakan bahwa "Inovasi strategi dan metode pembelajaran IPA yang dilakukan guru di kelas biasanya kurang berhasil karena dalam implementasinya kurang memperhatikan karakteristik siswa, termasuk perkembangan kemampuan berpikirnya". Hal ini berakibat pada kurangnya kemampuan memecahkan masalah yang dimiliki peserta didik secara umum, yang berdampak pada kesulitan dalam menguasai kemampuan mengolah informasi yang kompleks dan keterampilan berpikir ilmiah untuk mendukung kemampuan memecahkan masalah (PISA dan TIMSS dalam Nuh, 2013, hlm. 43)

Dalam standar kompetensi lulusan satuan pendidikan SMP dinyatakan juga bahwa lulusan peserta didik SD harus menunjukkan kecintaan dan kepedulian terhadap lingkungan (Mendiknas, 2006, hlm. 342). Upaya manusia dalam meningkatkan kualitas hidup menjadikan lingkungan sebagai obyek untuk memenuhi kebutuhan manusia dengan melakukan eksploitasi besar-besaran terhadap sumber daya alam yang hasil akhirnya berupa limbah.

Dalam pengamatan pendahuluan ditemukan bahwa peserta didik di tempat penelitian telah dikenalkan dengan sikap peduli lingkungan tetapi kurang mendapat pembentukkan sikap tersebut, rendahnya sikap peduli lingkungan peserta didik (mahasiswa) diakibatkan oleh proses pembelajaran yang dilakukan tidak memberikan solusi terhadap berbagai permasalahan yang terjadi. Peserta didik (mahasiswa) belum diajak berpikir untuk menyelesaikan permasalahan yang terjadi di lingkungan" (Titin, dkk. 2012).

Dampak dari kurangnya sikap peduli lingkungan menjadi faktor yang sangat mempengaruhi krisis lingkungan. Krisis lingkungan ini sedang dihadapi seluruh umat manusia pada saat ini sehingga memerlukan pemecahan masalah untuk krisis lingkungan tersebut (Adisendjaja, 2007, hlm. 3).

Salah satu model pembelajaran yang bertitik tolak dari suatu masalah adalah Problem Based Learning (PBL). Model ini berharap peserta didik dapat menjadi seorang pemecah masalah. Keberhasilan penggunaan pembelajaran yang dilakukan berdasarkan masalah dalam memunculkan kemampuan memecahkan masalah peserta didik dikemukakan oleh beberapa peneliti, di antaranya Arimba P. dkk. (2013), Rufaida, S. \& Sujiono, E.H. (2013) dan Sujarwanto, E. \& Hidayat, W. (2014).

Model problem based learning (PBL) dapat juga digunakan sebagai alat untuk menanamkan sikap peduli lingkungan. BPP Puskur (2011, hlm. 15) menyebutkan bahwa: "Pengembangan sikap peduli lingkungan yang dilaksanakan melalui kegiatan pembelajaran dapat menggunakan model pembelajaran berbasis masalah atau problem based learning (PBL)." Keberhasilan proses pembelajaran dalam meningkatkan sikap atau karakter 
dinyatakan pula oleh Afrizon, dkk. (2012), Titin dkk. (2012), Priadi, M. A. dkk. (2012), dan Khanafiyah, S. \& Yulianti, D. (2013).

Pendidik memiliki peluang besar untuk menumbuhkan kemampuan memecahkan masalah dan sikap peduli lingkungan dalam pembelajaran IPA. Materi pelajaran IPA dalam muatan kurikulum memadai untuk menjadi media penghubung antara pembelajaran yang berusaha untuk meningkatkan kemampuan memecahkan masalah dan sikap peduli lingkungan. Kelebihan model pembelajaran berdasarkan masalah dalam mengembangkan kemampuan memecahkan masalah dan sikap peduli lingkungan peserta didik disampaikan juga oleh Darmawan, E. (2009). Ketika peserta didik memiliki kemampuan memecahkan masalah. Peserta didik dapat menyelesaikan masalah tentang lingkungan nyata yang dirasakannya. Peserta didik yang menjadi pemecah masalah diharapkan menjadi peserta didik yang memiliki sikap peduli terhadap lingkungan.

Adapun tujuan dari penelitian ini adalah: 1) Mengkaji secara komprehensif aktivitas peserta didik dan guru dalam proses pembelajaran IPA dengan menggunakan model $P B L$; 2) Mengkaji dan menganalisis perbedaan peningkatan kemampuan memecahkan masalah antara peserta didik yang memperoleh model PBL dengan peserta didik yang memperoleh bukan PBL. 3) Mengkaji dan menganalisis perbedaan peningkatan sikap peduli lingkungan antara peserta didik yang memperoleh model $P B L$ dengan peserta didik yang memperoleh bukan $P B L$.

\section{B. METODE PENELITIAN}

Penelitian yang dilakukan adalah penelitian eksperimen dengan metode penelitian kuasi eksperimen, menggunakan desain penelitian rancangan kelompok-kontrol/ pra tes dan pos tes (Creswell, 2013, hlm. 242). Desain penelitian tersebut berbentuk:

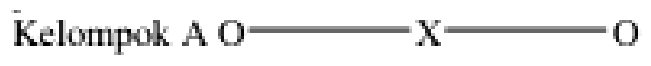

Kelompok B O-

Penelitian ini dilaksanakan di SMP Darul
Aminin NW Aikmual kecamatan Praya Tahun 2019 di semester genap tahun pelajaran 20182019. Dalam penelitian ini menggunakan instrumen tes dan non tes. Instrumen tes digunakan untuk mengukur kemampuan memecahkan masalah berbentuk soal uraian. Instrumen nontes berupa angket sikap peduli lingkungan eksplisit dan implisit serta lembar observasi keterlaksanaan $P B L$. Uji coba instrumen dilakukan untuk melihat validitas butir tes, reliabilitas tes, daya pembeda butir tes dan tingkat kesukaran butir tes. Selanjutnya data hasil uji coba instrumen dianalisis. Dari hasil analisis, yang digunakan dalam penelitian adalah soal-soal yang: memiliki tingkat kesukaran $0,00<\mathrm{IK}<1,00$ yang memiliki kategori sukar, sedang, dan mudah; mempunyai daya pembeda $0,20<\mathrm{DP}<1,00$ yang memiliki klasifikasi cukup, baik, dan sangat baik; mempunyai nilai validitas $r_{\text {hitung }}>$ dari nilai $\mathrm{r}_{\text {tabel }}=(0,423)$ yang memiliki derajat validitas cukup, baik, dan sangat baik; mempunyai nilai reliabilitas $r_{\text {hitung }}>$ dari nilai $r_{\text {tabel }}=(0,576)$ memiliki derajat relabilitas tinggi dan sangat tinggi.

Sedangkan untuk angket sikap peduli lingkungan dan lembar observasi keterlaksanaan $P B L$ hanya melalui proses validasi ahli saja. Data penelitian dikumpulkan melalui tes awal dan tes akhir yang digunakan untuk mengetahui kemampuan memecahkan masalah di kelas $P B L$ dan kelas bukan $P B L$. Sedangkan untuk mengukur sikap peduli lingkungan menggunakan angket SPL ekplisit dan implisit yang akan diisi oleh peserta didik sebelum dan sesudah pembelajaran baik di kelas $P B L$ maupun di kelas bukan $P B L$.

\section{HASIL DAN PEMBAHASAN}

1. Deskripsi pelaksanaan $P B L$.

Masalah yang dimunculkan dalam $P B L$ berusaha untuk memunculkan penyelesaian sementara yang beragam, sehingga timbul cara pencarian data yang beragam juga. Pencarian data yang dilaksanakan peserta didik adalah melakukan percobaan, studi pustaka, dan berkunjung ke tempat kejadian. Aktivitas pengumpulan data seperti yang dilakukan oleh peserta didik di atas sesuai dengan pelaksanaan mengumpulkan data dan eksperimen yang 
harus ada dalam $P B L$ yaitu fase pelajaran seharusnya lebih dari sekadar membaca tentang masalah itu di dalam buku (Arends, 2008, hlm. 59). Rancangan kelompok-kelompok penyelidikan dalam PBL berhasil memotivasi setiap anggota memberikan kontribusi pada kelompok yang terlihat dalam pengumpulan data, menyediakan kelengkapan alat, memahami tugas-tugas memecahkan masalah. Temuan ini sesuai dengan prinsip kolaborasi pada $P B L$ yaitu bekerja bersama-sama memberikan motivasi untuk keterlibatan secara berkelanjutan dalam tugas-tugas kompleks dan meningkatkan kesempatan untuk melakukan penyelidikan dan dialog bersama, dan untuk mengembangkan berbagai keterampilan sosial.

Berdasarkan rangkuman hasil observasi dapat simpulkan bahwa langkah- langkah $P B L$ yang direncanakan dalam RPP dapat dilaksanakan dengan lengkap. Dalam proses pembelajaran guru tidak banyak menerangkan materi kepada peserta didik. Kegiatan utama guru adalah membimbing peserta didik untuk menyelesaikan tugas-tugas sesuai langkahlangkah menyelesaikan masalah yang tersaji dalam LKPD. Kegiatan guru yang tidak banyak memberikan materi merupakan karakteristik khusus $P B L$. Penggunaan LKPD yang memuat masalah cukup membantu peserta didik dalam menyelesaikan masalah. Peserta didik yang tertib melalui langkah-langkah menyelesaikan masalah yang tersedia dapat menyelesaikan masalah dengan baik. Hal ini dapat diamati melalui LKPD yang dikerjakan oleh peserta didik. Temuan ini sesuai dengan hasil penelitian Soepudin (2014) yang menyatakan LKS berbasis masalah membantu siswa dalam memahami permasalahan/fenomena.

\section{Peningkatan kemampuan memecahkan masalah}

Tabel 1. Rangkuman hasil uji deskriptif dan statistik kemampuan memecahkan masalah.

\begin{tabular}{|c|c|c|}
\hline \multirow{2}{*}{$\begin{array}{c}\text { KELA } \\
\text { S }\end{array}$} & \multicolumn{2}{|c|}{$\begin{array}{c}\text { Kemampuan memecahkan } \\
\text { masalah }\end{array}$} \\
\cline { 2 - 3 } & $\begin{array}{c}\text { uji } \\
\text { statistik } \\
\text { deskriptif }\end{array}$ & $\begin{array}{c}\text { uji beda rata- } \\
\text { rata N-gain }\end{array}$ \\
\hline PBL & $\bar{\square}=0,440$ & $\begin{array}{c}\text { Lebih tinggi, } \\
\mathrm{t}(56)=\end{array}$ \\
\hline
\end{tabular}

\begin{tabular}{|l|l|c|}
\hline & & $\begin{array}{c}2,213> \\
\square_{\text {(स⿴囗口 }} .\end{array}$ \\
\hline $\begin{array}{l}\text { Non- } \\
\text { PBL }\end{array}$ & $\bar{\square}=0,281$ & \\
\hline
\end{tabular}

Dari tabel 1 menunjukkan terdapat perbedaan peningkatan kemampuan memecahkan masalah antara peserta didik yang memperoleh PBL $(\bar{x}=0,440)$ dengan peserta didik yang memperoleh pembelajaran bukan PBL $(\bar{x}=0,281)$. Peningkatan kemampuan memecahkan masalah peserta didik yang memperoleh $P B L$ lebih tinggi dibanding peserta didik yang memperoleh bukan $P B L, \mathrm{t}(56)=2,213>\mathrm{t}_{\text {tabel }}$.

Peningkatan kemampuan memecahkan masalah yang lebih baik pada kelas $P B L$ disebabkan rancangan masalah yang dimunculkan dan tujuan pembelajaran. Masalah yang dimunculkan adalah masalah nyata yang terjadi dalam kehidupan peserta didik. Peristiwa nyata yang mengandung masalah disajikan dalam media gambar. Dalam tampilan gambar tersebut disertakan informasi yang membuat masalah menjadi cukup kompleks untuk dicari pemecahannya. Rancangan penyajian masalah seperti yang diuraikan di atas ternyata cukup untuk membuat peserta didik untuk memberikan beragam jawaban sementara. Berdasarkan jawaban sementara yang dimiliki, setiap kelompok melakukan pengumpulan data atau informasi yang beragam. Perbedaan cara pengumpulan data tiap kelompok menghasilkan alternatif pemecahan masalah yang beragam pula. Pengetahuan alternatif dalam memecahkan masalah memperkaya pengetahuan peserta didik. Temuan ini sesuai dengan pendapat Sanjaya (2014, hlm. 216) bahwa masalah yang dimunculkan dalam $P B L$ adalah masalah yang terbuka. Penyelesaian masalah belum pasti sehingga peserta didik dan guru mendapat kesempatan untuk mengembangkan kemungkinan penyelesaian masalah. Sedangkan mengenai tujuan $P B L$, beliau menyatakan bahwa yang ingin dicapai dalam pembelajaran ini adalah kemampuan peserta didik untuk berpikir kritis, analitis, sistematis, dan logis untuk menemukan alternatif pemecahan masalah melalui 
eksplorasi data secara empiris dalam usaha menumbuhkan sikap ilmiah. Faktor penyebab lain adalah pengetahuan awal peserta didik kelas PBL $(\bar{x}=47,50)$ lebih baik dari kelas non PBL $(\bar{x}=43,62)$.

Kemampuan awal peserta didik berpengaruh pada keberhasilan peserta didik dalam menyelesaikan masalah. Peserta didik yang memiliki pengetahuan awal lebih baik memiliki pengetahuan prasyarat tentang cara mencegah kerusakan lingkungan yang lebih banyak. Pengetahuan prasyarat ini digunakan oleh peserta didik untuk memahami masalah yang terdapat dalam LKPD dan soal uraian yang mengukur kemampuan memecahkan masalah. Temuan ini serupa dengan hasil penelitian Rufaida, S. \& Sujiono, E.H. (2013) yang menyatakan bahwa terdapat interaksi antara model pembelajaran dengan pengetahuan awal dalam mempengaruhi kemampuan memecahkan masalah peserta didik. Kemampuan memecahkan masalah peserta didik pada kedua kelas, mengalami peningkatan. Hal ini disebabkan pada kedua kelas penelitian sama- sama menggunakan model pembelajaran yang menggunakan masalah untuk mengawali pembelajaran kemudian masalah tersebut harus dicari penyelesaiannya. Langkah-langkah pembelajaran yang dilakukan pada kedua kelas merupakan pembelajaran konstruktif yang membantu peserta didik dalam mengonstruksi pengetahuan secara mandiri melalui pengalaman yang diperoleh ketika berusaha memecahkan masalah.

3. Peningkatan sikap peduli lingkungan

\begin{tabular}{|c|c|c|c|c|c|}
\hline \multirow[t]{2}{*}{ Kelas } & \multicolumn{2}{|c|}{ SPL Eksplisit } & \multicolumn{3}{|c|}{ SPL Implisit } \\
\hline & $\begin{array}{l}\text { uji statistik } \\
\text { deskriptif }\end{array}$ & $\begin{array}{l}\text { uji beda rata- } \\
\text { rata N-gain }\end{array}$ & uji statisistik deskriptif & \begin{tabular}{|l|} 
uji beda rata-rata \\
N-gain
\end{tabular} & $\begin{array}{c}\text { Rata-ratata } \\
\text { wakktu }\end{array}$ \\
\hline PBL & $\bar{x}=0,355$ & $\begin{array}{l}\text { Lebih tinggi } \\
\text { (Asymp. Sig = } \\
0,002 . p<0.05)\end{array}$ & $\bar{x}=0,459$ & $\begin{array}{l}\text { Lebih tinggi } \\
\text { Asymp. Sig = } \\
0,012 . p<0,05\end{array}$ & 6 menit \\
\hline \begin{tabular}{|l|} 
Non- \\
PBL
\end{tabular} & $\bar{x}=0,187$ & & $\bar{x}=0,140$ & & 10 menit \\
\hline
\end{tabular}

Tabel 2. Rangkuman hasil uji deskriptif dan statistik kemampuan memecahkan masalah

Hasil uji statistik deskriptif dan statistik pada tabel 4.2. menunjukkan terdapat perbedaan peningkatan sikap peduli lingkungan eksplisit antara peserta didik yang memperoleh
PBL $(\bar{x}=0,355)$ dengan peserta didik yang memperoleh pembelajaran bukan PBL $(\bar{x}=0,187)$. Peningkatan sikap peduli lingkungan eksplisit peserta didik pada kelas PBL lebih tinggi dari kelas bukan PBL. (Asymp. Sig = 0,002, p < 0,05). Hal yang sama terjadi pada sikap peduli lingkungan implisit, terdapat peningkatan sikap peduli lingkungan implisit peserta didik yang memperoleh $P B L$ $\bar{x}=0,459)$ lebih tinggi dari peserta didik yang memperoleh bukan PBL $(\bar{x}=0,140)$, Asymp. Sig $=0,012, \mathrm{p}<0,05)$. Rata-rata waktu yang diperlukan kelas $P B L$ (6 menit) dalam mengisi angket lebih cepat dari kelas bukan $P B L \quad(10$ menit). Keadaan ini menunjukkan bahwa kelas $P B L$ memiliki sikap peduli lingkungan yang tinggi, karena peserta didik di kelas $P B L$ lebih berhasil mengenali pernyataan, gambar dan kombinasi kalimat dan gambar yang menyatakan sikap peduli lingkungan. Hal ini sesuai dengan cara kerja IAT bahwa respon yang semakin cepat diharapkan terjadi jika konsep yang sangat berhubungan dipetakan sebagai sesuatu yang identik dan bukan sebagai sesuatu yang berbeda (Wardani dan Analya, 2012). Keberhasilan pembelajaran berdasarkan masalah dalam meningkatkan sikap peduli lingkungan lebih tinggi dibanding pembelajaran lain di kemukakan dalam penelitian Priadi, M. A. dkk. (2012), Khanafiyah, S. \& Yulianti, D. (2013), dan Titin , dkk. (2012).

Peningkatan sikap peduli lingkungan yang dialami setelah peserta didik mendapatkan pembelajaran merupakan tujuan dari pengembangan sikap melalui pembelajaran. Setelah pembelajaran peserta didik mendapatkan pengetahuan baru tentang cara mencegah kerusakan lingkungan. Pengetahuan baru yang dimiliki oleh peserta didik menjadi pengetahuan moral yang digunakan untuk mengambil keputusan dalam bersikap dan berperilaku terhadap lingkungan. Pendapat yang sama diutarakan oleh Darmawan (2010).

Peningkatan sikap peduli lingkungan kelas $P B L$ lebih tinggi dari kelas bukan $P B L$ dapat disebabkan peserta didik mendapatkan masalah yang nyata dirasakan dalam kehidupan sehari- 
hari. Masalah tersebut harus dipecahkan penyelesaiannya secara bersama-sama dengan kelompoknya. Masalah dalam $P B L$ bersifat terbuka sehingga setiap peserta didik dapat mengembangkan penyelesaiannya melalui beragam cara pengumpulan data dan diskusi. Informasi atau data yang beragam dapat digunakan oleh peserta didik untuk menentukan beragam alternatif penyelesaian masalah. Pengetahuan berbagai alternatif penyelesaian masalah yang dimiliki menjadi pengetahuan baru bagi peserta didik. Pengetahuan baru tentang pencegahan kerusakan lingkungan ini menjadi landasan bagi peserta didik dalam bersikap terhadap lingkungan. Hal ini merupakan salah satu kelebihan dari PBL (Sanjaya, 2012, hlm. 221). Peningkatan sikap peduli lingkungan eksplisit dan implisit yang dimiliki kelas $P B L$ ada dalam kategori sedang, begitu pun pada kelas bukan $P B L$ mengalami peningkatan pada kategori rendah. Dengan hasil ini menunjukkan pengukuran sikap peduli lingkungan implisit melengkapi pengukuran sikap peduli lingkungan eksplisit. Hal ini menunjukkan IAT dan pengukuran eksplisit berhubungan. Temuan ini serupa dengan hasil penelitian Hafiyah, N., dkk. (2011). Dari tabel tersebut dapat kita lihat bahwa $P B L$ lebih berhasil dalam meningkatkan kemampuan memecahkan masalah dan sikap peduli lingkungan. Dapat kita amati juga bahwa peningkatan kemampuan memecahkan masalah berperan pada peningkatan sikap peduli lingkungan. Hal ini mencerminkan pembelajaran yang dikembangkan dalam penelitian berhasil meningkatkan kemampuan kognitif peserta didik. Peningkatan kemampuan kognitif ini berpengaruh pada sikap peduli lingkungan yang dimiliki oleh peserta didik. Hasil penelitian ini sesuai dengan hasil penelitian Priadi, M. A. dkk. (2012).

\section{SIMPULAN DAN REKOMENDASI 1. Simpulan}

Berdasarkan temuan dan pembahasan hasil penelitian dapat diambil simpulan sebagai berikut: pertama, aktivitas peserta didik dan guru dalam proses pembelajaran IPA dengan menggunakan model $P B L$ telah sesuai dengan karakteristik khusus yang harus ada dalam $P B L$. Kedua, terdapat perbedaan rata- rata peningkatan kemampuan memecahkan masalah antara peserta didik yang memperoleh $P B L$ ( $\bar{x}=0,440)$ dengan peserta didik yang memperoleh pembelajaran bukan $P B L \quad(\bar{x}=$ 0,281). Peningkatan kemampuan memecahkan masalah pada peserta didik yang memperoleh $P B L$ lebih tinggi dibanding peserta didik yang memperoleh bukan $P B L$, $t(56)=2,213>t_{\text {tabel }}$. Ketiga, terdapat perbedaan peningkatan sikap peduli lingkungan antara peserta didik yang memperoleh $P B L$ dengan peserta didik yang memperoleh pembelajaran bukan $P B L$. Peningkatan terjadi baik pada sikap peduli lingkungan eksplisit maupun sikap peduli lingkungan implisit. Peningkatan sikap peduli lingkungan eksplisit peserta didik yang memperoleh $P B L$ sebesar $\bar{x}=0,355$. Sedangkan peserta didik yang memperoleh pembelajaran bukan PBL sebesar $\bar{x}=0,187$. Peningkatan sikap peduli lingkungan eksplisit peserta didik pada kelas $P B L$ lebih tinggi dari kelas bukan $P B L$ ( Asymp. Sig $=0,002, \mathrm{p}<0,05)$. Peningkatan sikap peduli lingkungan implisit peserta didik yang memperoleh $P B L$ sebesar $\bar{x}=0,459$ dan peserta didik yang memperoleh pembelajaran bukan $P B L \bar{x}=$ 0,140. Peningkatan sikap peduli lingkungan implisit peserta didik yang memperoleh $P B L$ lebih tinggi dibanding peserta didik yang memperoleh pembelajaran bukan $P B L$ ( Asymp.Sig $=0,012, \mathrm{p}<0,05)$.

\section{Rekomendasi}

Rekomendasi yang muncul berkaitan dengan temuan penting dari penelitian ini, ditujukan pada pendidik dan pihak yang terkait dengan pendidikan terutama pendidikan tingkat sekolah dasar yang memiliki perhatian dalam pengembangan kemampuan memecahkan masalah dan sikap peduli lingkungan.

1. Kemampuan dalam memilih masalah dalam materi IPA dan melakukan langkahlangkah pembelajaran yang melatihkan kemampuan memecahkan masalah sangat diperlukan sehingga layak untuk dilakukan penelitian yang mengkaji kepemilikan 
kemampuan memilih masalah dan melakukan langkah- langkah pemecahan masalah pada pendidik.

2. Pelaksanaan Problem Based Learning $(P B L)$ yang berusaha meningkatan kemampuan memecahkan masalah dan sikap peduli lingkungan mengharuskan peserta didik bekerja dalam tim-tim penyelidikan, sehingga dibutuhkan penelitian yang memadukan Problem Based Learning (PBL) dengan teknik kerja kelompok yang lebih efisien dalam memanfaatkan waktu.

3. Dalam Problem Based Learning (PBL) peserta banyak melakukan aktivitas mandiri dalam mencari informasi. Hal ini memberikan peluang penelitian yang memadukan $P B L$ dan keterampilan peserta didik dalam mencari informasi baik melalui perpustakaan sekolah dan internet.

\section{DAFTAR PUSTAKA}

Adisendjaja, Y.H. (2007). Penerapan Pendidikan Lingkungan Di Sekolah. Seminar Open Mind Jurusan Biolgi FKIP Universitas Pasundan ( hlm. 120). Bandung: UNPAD.

Afrizona, R. \& Ratnawulan \& Fauzi, A. (2012). Peningkatan Perilaku Berkarakter Dan Keterampilan Berpikir Kritis Peserta didik Kelas IX MTSN Model Padang Pada Mata Pelajaran IPA-Fisika Menggunakan Model Problem Based Instruction. Jurnal: Jurnal Penelitian Pembelajaran Fisika 1, hlm. 1 -16.

Arends, R.I. ( 2008). Learning To Teach. Yogyakarta: Pustaka Pelajar.

Arimbawa P. \& Sadia I.W. \& Tika I.N. (2013). Pengaruh Model Pembelajaran Berbasis Proyek (MPBP) Terhadap Kemampuan Pemecahan Masalah IPA Sehari-hari Ditinjau dari Motivasi Berprestasi Siswa. e-Journal Program Pascasarjana Universitas Pendidikan Ganesha Program Studi IPA, Vol. 3.

Creswell, J.W. (2013). Research Design: Pendekatan Kualitatif, Kuantitatif, dan Mixed. Yogyakarta: Pustaka
Pelajar.

Darmawan, B., dkk. (2010). Hubungan Pengetahuan, sikap, perilaku dan Peranserta dengan Kesadaran Lingkungan Hidup serta kesanggupan Membayar Masyarakat sekitar bantaran sungai di Kota Pekanbaru. Journal of Environmental Sciences: Ilmu Lingkungan.

Hafiyah, N. \& Puri, A. \& Shadewi, R. (2011). Menguji Sikap Implisit Dengan Implicit Association Test. Makara: sosial humaniora, vol. 15 (2), hlm. 94- 108.

Khanafiyah, S. \& Yulianti, D. (2013). Model Problem Based Instruktion pada Perkuliahan Fisika Lingkungan untuk Mengembangkan Sikap Kepedulian Lingkungan. Jurnal: Jurnal Pendidikan Fisika Indonesia, 9, hlm. 35-42.

Nuh, M. (2013). Pengembangan Kurikulum 2013. Jakarta: Kemendikbud. Peraturan Menteri Pendidikan Nasional Republik Indonesia Nomor 23 Tahun 2006 Tentang Standar Kompetensi Lulusan Untuk Satuan Pendidikan Dasar dan Menengah.

Priadi, M. A. \& Sudarisman S. \& Suparmi. (2012). Pembelajaran Biologi Menggunakan Model Problem Based Learning Melalui Metode Eksperimen Laboratorium dan Lapangan Ditinjau dari Keberagaman Kemampuan Berpikir Kritis dan Sikap Peduli Lingkungan. Jurnal: Jurnal Inkuiri. Vol. 1 (3), hlm. 217-226.

Rufaida, S. \& Sujiono, E.H. (2013). Pengaruh Model Pembelajaran dan Pengetahuan Awal Terhadap Kemampuan Memecahkan Masalah Fisika Peserta Dididk Kelas XI IPA MAN 2 Model Makassar. Jurnal: Jurnal Pendidikan IPA Indonesia, 2 (2), hlm. 161-168

Samatowa, U. (2010). Pembelajaran IPA di Sekolah Dasar. Jakarta: Indeks.

Sanjaya, W. (2014). Strategi Pembelajaran Berorientasi Standar Proses pendidikan. Jakarta: Kencana Prenadamedia Group. 
JUPE: Jurnal Pendidikan Mandala

http://ejournal.mandalanursa.org/index.php/JUPE/index
Vol. 4. No. 5 Desember 2019

p-ISSN: 2548-5555 e-ISSN:2656-6745

Soepudin. U. (2014). Penggunaan Lembar Kerja Siswa Berbasis Masalah Dalam Pembelajaran IPA Secara Inkuiri untuk Meningkatkan Literasi Sains Siswa Sekolah Dasar. (Tesis.) Sekolah Pascasarjana, Universitas Pendidikan Indonesia, Bandung. 